\title{
Afvæbning af det sakrale
}

\author{
Om myte og allegori før og efter Luther \\ - tilløb til en teologisk læsning af Walter Benjamins \\ Ursprung des deutschen Trauerspiels
}

\section{LARS FELDVOSS}

Det allegoribegreb, Walter Benjamin i I925 lancerede $\mathrm{i}$ sin bog om det barokke sørgespil, og som siden skulle blive så ombejlet, lader sig ikke forstå blot som en litterær trope. Begrebet fungerer inden for en på én gang historisk og teologisk sammenhæng. Mere omstændeligt kunne man sige, at Benjamins læsning af den tyske barok udgør en kritisk reaktualisering af en litteraturhistorisk situation, i hvilken et teologisk problemkompleks af afgørende betydning for Benjamins egen tænkning synes at være sat på spidsen. Dette problemkompleks skal jeg via en slags spekulativ rekonstruktion af den barokke tilspidselsessituation forsøge at nærme mig, idet jeg, i højere grad end Benjamins fremstilling umiddelbart indbyder til, lægger vægt på reformationens betydning som historisk forudsætning for den tyske barok. Tilsyneladende begrænser Benjamin sig desangående til den konstatering, at sørgespilsforfatterne var lutheranere. Når han imidlertid samtidig tematiserer den barokke allegori som et vrangbillede af middelalderens allegoriske praksis, må man være opmærksom på, hvorledes reformationen tematisk klinger med som en begivenhed, der på afgørende vis sætter skel imellem de to allegoriformers historiske kontekst. For at kunne tage fat på dette spørgsmål er det nødvendigt først at se nærmere på allegoriens oprindelige funktion, regulering af den litterære omgang med mytestof og den teologiske baggrund for, at en sådan regulering har været så vigtig en sag inden for den kristne tradition.

Det jødiske billedforbud og myten om Kristus

Med titelordene til sit essay Aimer la Thora plus que
Dieu har Emmanuel Lévinas forsøgt at formulere kernen $\mathrm{i}$ den jødiske skriftreligion. Som jøde at erklære, at man elsker Torah'en højere end Gud, skal ifølge Lévinas forstås som "en beskyttelse imod vanviddet $\mathrm{i}$ en umiddelbar kontakt til det sakrale." Og i utilsløret polemik imod kristendommen fortsætter han: "forholdet imellem Gud og menneskene er ikke nogen sentimental forening $i$ en inkarneret guds kærlighed, men en forbindelse imellem ånder formidlet igennem en lære, Torah'en. Det er netop ved sin tale og ikke ved inkarnationen, at Gud lever iblandt os." I Jødens forhold til Gud bestemmes altså ikke først og fremmest ved kærligheden, men ved fordringen - en fordring, der udtrykkes ved, at Gud fra sin uantastede transcendens giver sit udvalgte folk en lovtekst, et materiale at arbejde ud fra, ikke ved, at han tager legeme og bliver nærværende. Den jødiske insisteren på distancen til Gud er, som Levinas' ordvalg vidner om, en defensiv manøvre: den beror på en fundamental frygt over for den direkte kontakt til det sakrale. Som det fremgår af det Gamle Testamente, befinder mennesket sig nemlig i konstant risiko for at blive inddraget $i$ overnaturlige magters tryllekreds. Også efter skænkelsen af lovtavlerne risikerer israeliterne således, når de glemmer den ene Guds fordring, at blive forfort af de lokale Ba'al-guder. Ikke for ingenting fremgår det af første bud, "Du må ikke have andre guder end mig", at der er alternativer. Den monoteistiske tro på den ene transcendente Gud betyder derfor ikke fornægtelsen af andre guddommelige magters eksistens, men netop erkendelsen af et behov for beskyttelse over for en pluralitet af immanente guder eller dæmoner.

PASSAge $49-2004$ 
Den jødiske monoteisme tiltror ikke mennesket evnen til at skelne imellem gode og onde guddommelige manifestationer. Derfor er det afgørende for den at fastholde, at kun igennem den fordrende Torah - som i Levinas' terminologi er hellig og ikke sakral, dvs. den er givet af Gud, men udgør ikke noget gudsnærvær - står mennesket i relation til det guddommelige. Så snart et jordisk legeme dyrkes som Guds nærvær, står dørene åbne for alverdens dæmoniske kræfter. Heraf kommer det jødiske billedforbud, Moselovens andet bud: "Du må ikke gøre dig noget udskåret billede eller noget afbillede af det, som er oppe i himmelen eller nede på jorden eller i vandet under jorden; du må ikke tilbede eller dyrke det". I forbudet skinner en fundamental frygt for selve den æstetiske billeddannelse igennem: Billedet forstås ikke blot som et tegn, der for så vidt ville vidne om en vis distance til selve guddommen, men frygtes i formningsprocessen selv at få karakter af en dæmonisk magt. Dette viser sig i historien om Aron og guldkalven i Anden Mosebog, 32, 24. Som Aron bekender over for Moses: "Da sagde jeg til dem [israeliterne]: De, der har guldsmykker, skal rive dem af! De bragte mig da guldet, og jeg kastede det $\mathrm{i}$ ilden, og så kom denne tyrekalv ud deraf". Kalven selv er altså den aktive i processen. Der sker et omslag fra kunstnerisk beherskelse til dæmonisk besættelse, hvorved det tilbedte billede selv synes at have taget magten over billedskabelsen.

$\mathrm{Nu}$ lyder på sin side det kristne budskab, at Gud er blevet kød. Guds søn vandrer blandt menneskene, gør undere og skaber dermed lige netop en tilstand, der i jødiske øjne må fremstå som "vanviddet $i$ en umiddelbar kontakt med det sakrale". Og mindre vanvitigt bliver det $\mathrm{i}$ jødiske øjne ikke efter Kristi himmelfart, på pinsedagen, hvor en ånd farer i di-

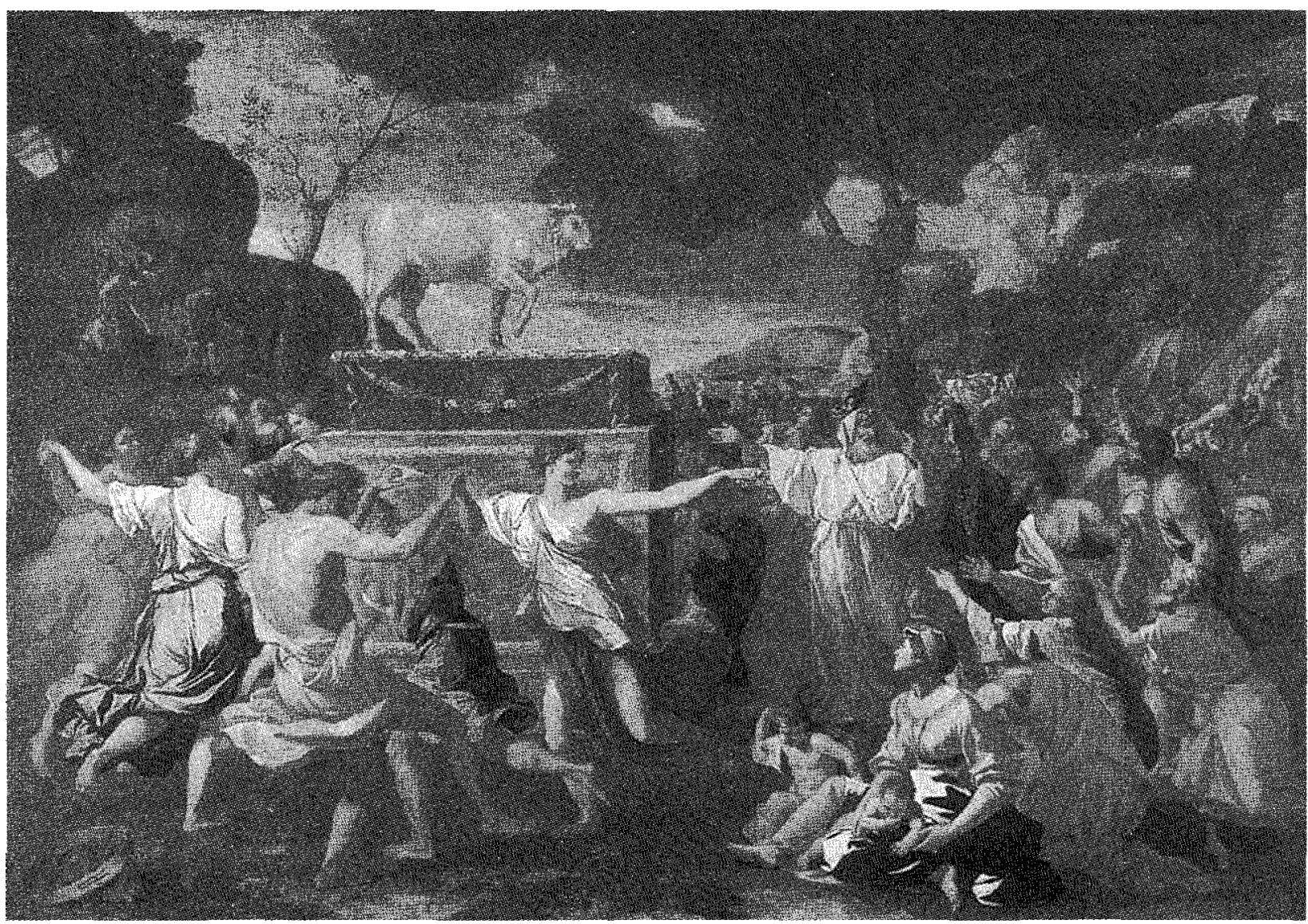

Guldkalven tilbedes, Nicolas Poussin, ca. I634 
sciplene og tager magten over dem: "Da”, læser man i Apostlenes Gerninger, 2, 2, "lød der med ét fra Himmelen en susen som af et vældigt åndepust, og den fyldte hele huset, hvor de sad. Og der viste sig for dem tunger som af ild, og de fordelte sig og satte sig på hver enkelt af dem. Og de blev alle fyldt med Helligånd, og de begyndte at tale $i$ andre tungemål, efter hvad Ånden gav dem at forkynde”. I denne sakrale ekstase forrykkes disciplene fra Torah'en og fordringen som holdepunkt og bliver kristne. Den uendelige afstand til Gud, som spejledes i dennes uendelige, men dog ved Loven håndgribelige fordring til mennesket, ${ }^{2}$ opløses $\mathrm{i}$ det kristne budskab om den definitive forløsning i Guds nåde og Gudsrigets snarlige komme - en forløsning, hvis altafvæbnende symbol er Kristus.

Ligesom den hedenske kult tager kristendommen altså sit udgangspunkt $i$ en ekstatisk erfaring af gudsnærvær og kan i den forstand kaldes en mytisk religion. Ifølge den tyske teolog Wolfhart Pannenberg skal myten defineres som en billedlig fortælling om guddommelige og for menneskets verden konstituerende urhandlinger - urhandlinger som i den kultiske dyrkelse genaktualiseres, for at mennesket kan tage del i dem og således så at sige blive ét med sin verden. Denne model finder Pannenberg f.eks. i det antikke Grækenlands sammenhæng af myte og kult. Heller ikke jødedommen kan ifølge Pannenberg sige sig fri for mytiske elementer, men fundamentalt markerer den sig som umytisk i kraft af forestillingen om syndefaldet. Ved syndefaldet er mennesket nemlig uigenkaldeligt adskilt fra urhandlingerne, dvs. skabelsen. Det befinder sig i en radikalt ny situation, som ikke kan forløses ved genaktualisering af urhandlingerne. Jøden kan derfor ikke gå op i sin verden og må operere med uforløste fortællefigurer som udvandringen, forjættelsen og fordringen. Ifølge den kristne myte derimod er verden - hvordan det så end skal udlægges - givet på ny, og dette netop ved en guddommelig handling: Guds tagen legeme, selvofring og genopstandelse. Nok er Jesus en profet i den jødiske tradition, men, hævder Pannenberg, han fremtræder samtidig selv som opfyldelsen af profetien:
Guds vilje er allerede her og nu herskende i de menneskers liv, der fuldt og helt har indstillet sig på Guds kommende herredømme. Dermed blev Jesus med sit budskab om Gudsherredømmets komme selv til fuldbyrdelsen af dettes nærvær, selve Guds nærvær.3

Dyrkelsen af den gudsbilledlighed, som denne myte om Kristus udgør, fører i den kristne kult - ikke aldeles ulig hvad der skete med Arons Guldkalv - til aktualiseringen af gudens nærvær. "At dø og genopstå med Kristus," fastslår Pannenberg således, "det har siden Paulus været ledemotivet i den kristne selvforståelse"(SM, SI8).

Fra et jødisk synspunkt må alt dette slet og ret betegnes som afgudsdyrkelse. En jødisk kritik af den kristne nærværsreligiøsitet finder man således i nyere tid ikke bare hos Lévinas og hans tilhængere. Den gør sig også gældende i den kritiske teori, f.eks. hos Adorno og Horkheimer, der betegner Jesus Kristus som “den forgudede magiker” og mere end antyder, at det ikke gør stor forskel, om man i den ekstatiske oplevelse af forløserens aura råber 'Hosianna' eller 'Heil'. 4 På beslægtet vis spiller den jødiske dæmonfrygt og billedforbuddet en rolle $\mathrm{i}$ Walter Benjamins mytekritik. Som Cristoph Lienkamp skriver: "Benjamin står - i traditionen efter det jødiske billedforbuds dialektik - ligesom Heidegger, Levinas og Derrida, i opposition til nærværstænkningen".5 Den mekanisme som jødedommen med historien om Aron og guldkalven advarer imod - omslaget fra menneskelig beherskelse til mytisk besættelse - er så at sige det teologiske forlæg for den, der i en mere historiserende diskurs går under navnet oplysningens dialektik.

Kristendommen præges imidlertid selv af en jødisk arv. Side om side med sine mytiske elementer bærer den monoteismens oprindelige frygt for dæmoniens magt med sig. Igennem sin historie har kristendommen til stadighed stået over for problemet, hvorledes den ene Guds nærvær kan aktualiseres, uden at de dæmoniske guder også aktualiserer sig. Idet de kristne lod den ene Gud blive immanent, glemte billedforbuddet og $\mathrm{i}$ stedet opfyldtes af Helligånden, inviterede de nemlig i ekstasen også de hedenske guder med til fejringen. Som Pannenberg skriver: 
Den nye Mythos om den evige Gudssøns åbenbaring i form af Jesus fra Nazareth blev i den kristne overlevering til udgangspunktet for en kristen recepion af hellenismens mytiske forestillinger, som på denne måde blev indlemmet i den kristne livsverden. (SM, 523)

Da det, som det fremgår af billedforbuddet, er ved billedets fortryllende magt, at dæmonien træder ind i verden, angår spørgsmålet om forvaltningen af gudsnærværet selve omgangen med myten som billedliggørelse af det guddommelige: hvorledes kristendommen skal forholde sig til det hedenske materiale, som den selv fører med sig, og som - bl.a. i litteraturen - er forblevet aktivt, også efter at kristendommen officielt blev den eneste vestlige religion. Ud fra den fundamentale dæmonfrygt har man let kunnet tænke sig, at også en ren litterær dyrkelse af den hedenske mytologi risikerer at vække nye guldkalve. Set på den baggrund er det er ikke overraskende, hvis dæmonfrygten i århundrederne efter renæssancen, som Trauerspielbogen behandler, blusser op som reaktion på en intensiveret dyrkelse af antikken. For, som Benjamin skriver:

“Prudentius' spådom: Renset for al blod vil marmoret endelig stråle; uskyldige vil de bronzefigurer stå, der i dag betragtes som idoler", denne spådom er endnu ikke tolvhundrede år senere gået i opfyldelse. For barokken, ja sågar for renæssancen bevarede antikkens marmor- og broncekulpturer noget af den gru, med hvilken Augustin havde oplevet dem "som gudernes legemer”. (UT, 200)

Det er her, allegorien for Benjamin kommer ind $\mathbf{i}$ billedet. Inden jeg kan tage fat på Benjamins barokke udgave, skal det dog kort handle om den allegoriske praksis, som den fandt sted i middelalderen.

\section{Middelalderallegorien}

Det er altså, hvis man skal systematisere, relevant at skelne imellem fire gudsnærværsfaktorer: $\mathrm{I}$. den kristne kult, dvs. kirkeritualerne, 2. det kristne mytestof (mytologi), dvs. kristendommen som litterært fænomen, 3. den hedenske mytologi og 4. Hellig- ånden. Udgangspunktet for det følgende er den opfattelse, at middelalderkirken - som løsningen på det skitserede 'forvaltningsproblem' - tilstræbte en fastholdelse af kirkeritualet som kristendommens centrum, dvs. som den eneste adgang $\mathbf{i l}$ det egentlige gudsnærvær. ${ }^{6}$ Den rituelle deltagelse i Kristus-skikkelsen og dennes mytiske urhandlinger finder sted $\mathrm{i}$ kirken, frem for alt i forbindelse med nadverritualet. Kirken har på den måde så at sige monopol på Guds symbolske præsens. Ganske vist kan forestillingen om Helligånden siges at indebære, at Gud er nærværende $i$ alle troende individer uafhængigt af den institutionelle forvalming, men kontrollen over helligåndslærens ekstatiske potentiale, som kunne frygtes at give anledning til spredte udskejelser under henvisning til den hellige inspiration, synes også netop at have været en afgørende sag for middelalderkirken. Dette problem spillede således en vigtig rolle i den såkaldte filioque-strid, som førte til splittelsen imellem romerkirken og den græsk-ortodokse kirke i ro54. ${ }^{7}$

Ligesom romerkirken måtte holde Helligånden $\mathrm{i}$ stramme tøjler, måtte den forsøge at kontrollere mytologien, dels den bibelske, dels den hedenśke, som kristendommen havde indoptaget, og som gjorde sig gældende i middelalderens religiøse litteratur. Et afgørende middel i den forbindelse var allegorien. Hos Hans Robert Jauss finder man allegoriens funktion formuleret netop i forhold til myten som litterær nærværserfaring:

Allegorien adskiller sig derved fra den poetiske Mythos, at den ikke selv indbefatter sin læsning, men fra første færd er baseret på dobbelt-betydning. Her behøver lytteren eller læseren en nøgle, før han kan forstå den anden betydning, som ligger gemt bag ordlyden. Har han nøglen, er "bogstavets dunkelhed" med et slag ophævet, og den skjulte mening fremdraget i lysende klarhed og uimodsigelig entydighed. ${ }^{8}$

Allegoriens positive funktion, dens mulighed for at lade den litterære eller mytologiske fortælling henvise til "et mere", en dybere indsigt, træder i denne sammenhæng i baggrunden til fordel for den vigtigere negative funktion, at hindre "bogstavets dunkelhed" $i$ at antyde for meget og dermed overvælde 
eller forføre læseren. Allegoriens konventionalitet reducerer med andre ord den poetiske Mythos' slyngninger til blotte tegn for et entydigt budskab.

Forudsat er den antagelse, at religiøse fortællinger alene ved at blive fortalt kan udvikle sig til virkelighed, nøjagtig som den kristne fortælling i nadverritualet menes at blive kød og blod. Ved at præsentere religiøse fortællinger på en måde, som konsekvent signalerer, at ikke i den litterære fremstlling selv, men kun i den guddommelige virkelighed, som den henviser til, findes gudsnærværet, forsøger allegorien derfor at forhindre den religiøse litteratur $i$ at udvikle sig, som guldkalven gjorde over for Aron. Den centraliserer med andre ord gudsnærværet ved at fremhæve den litterære pluralitets uegentlighed $\mathrm{i}$ forhold til det egentlige: Kristus som man møder ham i nadverritualet. Et sådant formål tjente middelalderallegorien både $\mathrm{i}$ omgangen med den bibelske og den hedenske mytologi og både - som hhv. allegorese og allegorisk digtning - på receptions- og produktionsniveau. Den var med til at holde bibeludlægningen inden for visse konventionelle rammer. Samtidig blev den brugt til at læse det kristne budskab ud af hedenske klassikere som Homer og Vergil. Endelig spillede allegorien en afgørende rolle i forbindelse med den nyskrevne litteraturs omgang med den hedenske mytologi. De mytologiske fortællinger kunne bringes til entydigt at referere til den kristne frelseshistorie, eller guderne kunne reduceres til allegoriske personifikationer af menneskelige lidenskaber, dyder og laster, som så af den allegoriske sammenhæng placeredes $i$ et af kirken indrettet moralsk hierarki.

I middelalderkirkens bestræbelse på at centralisere gudsnærværet synes strategien over for det hedenske materiale således at have gået ud på brug og beherskelse snarere end fortrængning og udslettelse. Frataget sin symbolske udstråling fik mytologiens mange gudebilleder lov til som allegorier at henvise til kristendommens ene centrale symbol. Mens allegorien på den måde lod det hedenske mytestof gøre god gavn, muliggjorde den således også dets fortsatte overlevelse, så det ikke blot kunne ligge klar til sin genopblomstring i renæssancen, men tilsyneladende allerede kunne påbegynde denne opblom- string under dække af middelalderallegoriens legitimitet. Dette konstaterer f.eks. Karl Borinski:

Den ugenerthed, hvormed dengang (op til og omkring år 500) selv biskopper som Sidonius og frem for alt Ennodius satte mytologien i omløb i kristne digte, retfærdiggjorde brugen og tillod den aldrig helt at forsvinde; Dante vovede således med sin Musa, sin Phebo og sin Giove på ingen måde noget nyt. De kristne renæssancedigtere, som gik særdeles langt i denne henseende, kunne henvise til den kanoniske tidsalders autoritet. 9

Jauss har med eksempel i den såkaldte 'Minneallegori' skildret, hvorledes senmiddelalderdigtningen i sin anvendelse af hedensk materiale gradvist løsriver sig fra allegoriens herredømme. Dette sker ved, at digterne $i$ "et bevidst spil med elementer af poetiskmytisk effekt, esoterisk lære og lagdelt afkodning"(AR, I9I) begynder at forhale udleveringen af den nøgle, som skulle sikre den entydige oversættelse af allegoriens bogstavelighed til det kristne budskab. Idet de litterære figurers entydighed sløres, unddrager de sig den allegoriske omskrivning, og de kan - som det f.eks. ifølge Jauss er tilfældet med Venusskikkelsen i Roman de la Rose, skrevet omkring 1234 af Guillaume des Lorris - komme til at fremtræde som uudgrundelige magter, der indvirker på handlingsgangen: "Uimodståeligt udøver hun den virkning, som faklen repræsenterer, hun foranlediger handlingens omslag, efterlader den største forvirring og signalerer således i kraft af sin tilsynekomst, indgriben og forsvinden en overmenneskelig mytisk magts numinøsitet”(AR, 193). Under dække af den kanoniserede allegoriske praksis kunne der på den måde $\mathrm{i}$ form af Minne-digtningen udvikle sig et forum for dyrkelse af menneskelige lidenskaber som guddommelige/dæmoniske magter, som at dømme efter Jauss' beskrivelse ikke stod tilbage for den hedenske kultvirksomhed: "Den elskende, som treder i Amors tjeneste, bringer sig i umiddelbar forbindelse med det numinøse"(AR, 197).

Man må altså forestille sig, hvorledes den mytologiske digtning efterhånden, som middelalder bliver til renæssance, frigør sig fra middelalderallegoriens kontrollerende greb og foranlediger en genopvækkelse af 
de hedenske guder, "således at", som Jauss konkluderer, "den for længst assimilerede og nu kun citerede Mythos pludselig fremtræder i en magtfuldhed, som overrumpler den allegoriske fiktion"(AR, 196). Tilsyneladende kunne dette ske uden at udløse afgørende reaktioner fra kirkeinstitutionens side. Det var således "på ingen måde", skriver Borinski, "fra teologiens side, men derimod inden for den kunstneriske poetik, at man først med held gik i rette hermed, vel at mærke først på modreformationens tid, hvor kritikken i begge lejre, især i det 17 . århundredes Tyskland, bliver særdeles heftig" (AP, II, 22). Det er netop denne tyske reaktion, Walter Benjamin behandler i sin bog om det barokke sørgespil. Ligesom Borinski peger Benjamin på den poetikalske reaktion, men det er frem for alt $\mathrm{i}$ det tyske sørgespil, at han ser barokken tage kampen op imod den mytiske digtning. Denne kamp kommer ifølge Benjamin til udtryk i genoptagelsen af den allegoriske teknik.

\section{Den barokke allegori}

Den barokke allegori befinder sig imidlertid i en anden situation end middelalderallegorien. Den synes ikke på samme måde at kunne holde sig til den veldefinerede opgave at henvise til det centrale kristne symbol. I Benjamins udlægning fremtræder allegorien ikke længere som en kontrolleret brug af de mytologiske figurer, renæssancedigtningen genoptog fra antikken, men som en desperat ødelæggelse af dem: "Denne teknik", hedder det således, “tilsigter en eksalteret beherskelse af antikke elementer i en konstruktion, der, ikke ved at samle dem $i$ en ny helhed, men derimod i ødelæggelsen, skulle være de antikke harmonier overlegen" (UT, I56). Middelalderallegorien skulle uskadeliggøre mytologien som sakral erfaring ved at fremhæve den mytologiske teksts uegentlighed $\mathrm{i}$ forhold til det egentlige gudsnærvær $\mathrm{i}$ Kristus. For den barokke allegori er det ikke tilstrækkeligt med en sådan fremhævelse af uegentlighed. De mytologiske figurer må sønderdeles for som ruinstumper at kunne indgå $i$ det barokke værk.

Den barokke allegori indebærer altså ikke blot en reduktion af det mytologiske materiale til tegnets arbitrære funktionalitet: Fremhævelsen af arbitrariteten indgår $i$ en generel erfaring af den faldne verdens fordærv. Ligesom det menneskelige legeme er de mytologiske guder for sørgespillets melankolske blik først og fremmest udtryk for denne faldenhed, hvorfor enhver erfaring af retfærdiggørelse eller afrundet meningsfuldhed, som en æstetisk fremstilling af legemet eller guderne måtte postulere, må modarbejdes af allegorien:

Fuldstændig afgørende for udformningen af denne tankegang var det nemlig, at det åbenlyst måtte fremtræde således, at ikke alene forgængeligheden, men også skylden, havde taget bolig i såvel afguder som legemer. Det er ikke det allegorisk betydende beskåret i sig selv at finde sin meningsopfyldelse [Sinnerfüllung](UT, 200).

Frem for at samle sig omkring Kristus og kirkeritualerne som gudsnærvær orienterer den barokke allegori sig på den måde imod det mytologiske materiale som gudsforladthed.

Det er almindeligt i Benjamin-litteraturen at forstå den melankolske erfaring som en omstændighed, en betingelse for den barokke allegoris opståen. Således f.eks. hos Christoph Lienkamp:

Årsagen til disse formers opståen ligger vel i opløsningen af den middelalderlige orden og dennes transcendensforståelse - inden for hvilken alting har sin af Gud forudsete plads - i erfaringen af en kaotisk og gudsforladt verden, berøvet sin metafysiske substans og dermed enhver værdi (MU, 43).

Som et alternativ til denne absurdistisk sindede Benjamin-reception, vil jeg her foreslå en opfattelse af melankolien som en bestrabelse og ikke en omstandighed for den barokke allegori. Når det ovenfor hedder, at sørgespillets materiale "åbenlyst måtte fremtræde" [scheinen musste] som gudsforladt, kan der være tale om en fordring snarere end en beskrivelse af et vilkår. At mytologien fremtræder som meningsløs og fragmenteret kreaturlighed, skyldes ikke, at den ikke kan andet, men at det er allegoriens opgave at fremstille den således. Et alternativ til gudsforladtheden er der nemlig i Trauerspielbogen: gudebilledernes fortsatte aktivitet som dæmonisk inkarnation. Som tidligere citeret fastholder Benjamin, at "for barokken, ja sågar for renæssancen bevarede antikkens marmor- 
og bronzeskulpturer noget af den gru med hvilken Augustin havde oplevet dem "som gudernes legemer"(UT, 200). Tilsyneladende beror den barokke allegoris melankoli altså ikke på ikonernes livløshed, men på behovet for at værne imod deres livagtighed - ikke på erfaringen af meningsløshed, men på behovet for at bekæmpe en dæmonisk meningsfuldhed. ${ }^{\text {Io }}$

I modsætning til den antikke tragedie, der ifølge Benjamin iscenesætter menneskets kamp imod guderne og med heltens offerdød udsiger en forjættende protest imod den mytiske overmagt, fremtræder martyrens død i sørgespillet ganske rigtigt som et mellemværende imellem martyren og en dennesidig verden, der endnu ikke har indset sin gudsforladthed. "Martyrdøden", skriver Lienkamp, "er en appel til de endnu levende om at indse, at verden er forgængelighedens domæne, om at afsløre den som dødelighedens og værdiløshedens skueplads” (MU ,87). Men selve denne fremstilling af den faldne verden som tømt for gudsnærvær beskriver Benjamin som et værn imod netop de symbolske formers egen dæmoniske nærværserfaring. Sørgespillets melankoli er med andre ord ikke deskriptiv men normativ - en påmindelse om, at man ikke bør dyrke anden guddommelighed end den fraværende. Det er tydeligt, at Benjamin med sin udførlige omtale af periodens dyrkelse af astrologi, verdensfortolkning og ekstatisk religiøsitet ikke forsøger at fremmane billedet af meningsforladthed, men derimod af en tilstand præget af de stadige omslag imellem en arbitraritetserfaring og en erfaring af de betydningsbærende genstandes alt for meningsfulde sammensværgelse. Det skal medgives, at andre af Benjamins formuleringer kan give anledning til opfattelsen af melankolien som en omstændighed, men vælger man udelukkende at betragte sagen således, må man negligere alle de formuleringer, $i$ hvilke Benjamin beskriver den mytiske billedlighed, ikke som død, men som truende, og det allegoriske, ikke som besiddelsen af et allerede fragmentarisk materiale, men som fragmenterende handling.

Afgørende for tankegangen i Trauerspielbogen er således den fortsatte relevans af den jødiske uvilje over for det sakrale og den betænkelighed ved den æstetiske billedskabelse, som følger heraf. Som led i
Trauerspielbogens opgør med den tyske klassicismes dyrkelse af symbolet citerer Benjamin en passage fra Aby Warburgs Heidnisch-antike Weissagung in Wort und Bild zu Luthers Zeiten:

Siden Winckelrnann er den klassisk forædlede antikke gudeverden i den grad blevet os indprentet som symbol på det antikke overhovedet, at vi helt har glemt, at den er en nyskabelse fra den humanistisk dannede kulturs hånd. Denne 'olympiske' side af antikken måtte først fravristes den nedarvede dæmoniske side. For siden oldtidens slutning hørte de antikke guder som kosmiske dæmoner vedvarende til det kristne Europas religiøse magter...". ${ }^{\text {II }}$ Klassicismen har med andre ord ikke forstået sagens alvor. Den tror i det symbolske at kunne finde ikke det afvæbnende gudsnærvær, men derimod den menneskelige skabelses apoteose, "menneskets ophøjelse i det ikke blot sædeligt fuldendte individ"(UT, I39).

Når Benjamin kritiserer klassicismen for at forvrænge symbolbegrebet, er det ikke for at forsvare det egentligt symbolske, men for at advare imod en undervurdering af dets magt. Det egentligt symbolske må ifølge Benjamin forstås i teologiske termer, som "enheden af den sanselige og den oversanselige genstand, det teologiske symbols paradoksi" (UT, I38) - altså inkarnationen, som den finder sted i Kristusskikkelsen og i nadverritualet, men også i forbindelse med Arons guldkalv; som den kan sætte sig igennem i den poetiske Mythos og måske kan overrumple klassicisten og andre, der i dyrkelsen af den symbolske kunst glemmer dæmoniens mulighed. Det er dette symbolske, den barokke allegori bekæmper: "Hvor symbolet er ved at opsluge mennesket, skyder allegorien ud af værens grund, konfronterer intentionen og slår den således for panden" (UT, I6I). Ved denne destruktivitet adskiller den barokke allegori sig afgørende fra middelalderallegorien. Det er i håb om at blive klogere på denne historiske forskel, at jeg $\mathrm{i}$ det følgende vil kigge nærmere på den lutherske reformation.

\section{Allegorien hos Martin Luther}

"Barokkens store tyske dramatikere var lutheranere", konstateres det i Trauerspielbogen. Nogen eksplicit analyse af reformationens konsekvenser for 
forvaltningen af gudsnærværet finder man dog ikke hos Benjamin, der først og fremmest peger på, hvorledes Luthers retfærdiggørelseslære stimulerede barokdigternes melankoli: "De menneskelige handlinger var blevet berøvet al værdi. Noget nyt opstod: en tom verden" (UT, II9). Da forvaltningsproblemet imidlertid er afgørende for Benjamins forståelse af den barokke allegori, og Luthers teologi på sin side har medført afgørende omvæltninger og modsigelser for den kristne forvaltningsbestræbelse, vil det kunne betale sig at kigge nærmere på, hvorledes Luther forholder sig til de fire gudsnærværsfaktorer hhv. kirkeritualet, kristen og hedensk mytologi og Helligånden - for på denne baggrund at få presset lidt mere ud af Benjamins formuleringer.

Selv om Luthers lære tager sit udgangspunkt i angrebet på romerkirken som institution, må man afvise den opfattelse, at Luther ville en frigørelse af religiøsiteten fra kirkeinstitutionen. Som Jochen Hörisch fastholder:

Over for alle gængse klichéer må der fortsat huskes på, at Luther faktisk i bogstaveligste forstand tilsigtede en reformation, en genoprettelse af det, som en mere og mere forsømmelig kirke var parat til at sætte over styr: Eukaristiens og den kristne forjættelses alvor (BW, II5).

Det, Luther reagerede over for, var altså ikke kirkeinstitutionen, men derimod dennes udvanding $i$ kraft af dens tiltagende eftergivenhed over for og indoptagelse af renæssancens nyhedenskab. Denne eftergivenhed var han blevet vidne til i isıo på sin rejse til Rom, hvor man dengang var $i$ gang med den renæssance-inspirerede og aflads-financierede ombygning af Peterskirken. Over for en kirkemagt, der var ved at foretage en "fornyelse af den kristne kunst i antikkens polyteistiske ånd" (BW, II3), måtte Luther insistere på kristendommens ene inkarnation, på forkyndelsen af Kristus og på den rituelle deltagelse $\mathrm{i}$ denne $\mathrm{i}$ forbindelse med dåb og nadver.

Også Luthers strid med de såkaldte 'sværmere', dvs. spiritualistiske prædikanter som Thomas Müntzer og Andreas Karlstadt, giver det indtryk, at hans ønske var en fortsat centralisering af den sakrale er- faring. Inspireret af Luthers brud med romerkirken havde spiritualisterne udviklet en teologi, der på bekostning af sakramente og forkyndelse lagde hovedvægten på Helligånden som en indre guddommeliggørende kraft i det kristne menneske, en kraft med hvilken Guds rige på jord her og nu kunne realiseres: "Således", skriver Franz Lau, "synes Müntzer at have drevet den tanke, at udelukkende besiddelsen af Ånden bestemmer den kristne, så vidt, at sakramenterne i det hele taget blev ham ret uvigtige". ${ }^{12}$ Stillet over for helligåndsprædikanterne og de mere eller mindre ekstatiske folkelige bevægelser, som de stimulerede, måtte Luther, ligesom middelalderkirken havde gjort det, forsøge at modarbejde helligåndsforestillingens centrifugaleffekt ved at fastholde forkyndelse og sakramente som kristendommens centrum. "For", som han skriver i et skrift imod Karlstadt, "Gud vil ikke give nogen ånden eller troen uden det ydre ord og tegn, som han har givet til dette formål". ${ }^{13}$ For at fastholde nadverritualets status bruger Luther derfor megen energi på at tilbagevise Karlstadts forsøg på at så tvivl om rigtigheden af nadver-ordene: "dette er mit legeme":

Hvad betyder Karlstadts drømmeri, spotteri og skumleri? Jeg ser her Guds direkte, klare og magtfulde ord, som tvinger mig til den bekendelse, at Kristi legeme og blod skal være i sakramentet (WP, I64).

Hvad angår Helligånden og den hedenske mytologi, synes Luthers lære altså umiddelbart at videreføre middelalderkirkens centraliseringsbestræbelse. Hvad angår forvaltningen af den kristne mytologi, indebærer Luthers reformation imidlertid omvæltninger, som kan være relevante for forståelsen af Benjamins tematisering af den barokke allegori. Som et led i opgøret med romerkirken forkaster Luther nemlig den kanoniserede allegoriske praksis. Dette kan man følge i et skrift fra ISI2 med smædetitlen Auff das uberchristlich, ubergeistlich und uberkunstlich buch Bock Emsers zu Leipzig. Som næunt var formålet med den allegoriske bibeludlægning frem for alt at fremhæve mytologiens, dvs. selve bibeltekstens uegentlighed $\mathrm{i}$ forhold til det egentlige gudsnærvær i kirkeritualet og dermed værne imod den litterære gudsbilledlig- 
heds mytiske magt. Allegorien skulle fremhæve afstanden imellem teksten som tegn og den åndelige realitet, som den refererede til. Luther afviser imidlertid dette skel: "Skriften lader sig ikke sådan opdele i bogstav og ånd". ${ }^{4}$ Når Hieronimus Emser ønsker at fastholde det allegoriske greb om teksten, kan det derfor i Luthers øjne kun være udtryk for klerikalt magtbegær.

Med forkastelsen af skellet imellem bibelteksten og det egentlige nærvær opstår den lutherske forestilling om 'Ordet'. Ordet henviser ikke til den gudshandling, som indstiftede kristendommen, det er denne gudshandling: Is "Det ny testamentes prædiken", hedder det, "indebærer hverken mere eller mindre end, at Kristus ud af Guds barmhjertighed tilbydes og præsenteres [ikke repræsenteres] for alle mennesker"(BE, 87). Det er denne forestilling om testamentet som Guds Ord, og ikke sakramentet, der indtager den centrale plads i Luthers forvaltning af gudsnærværet. Som vist ovenfor forsvarede han nadverens status over for helligåndsprædikanterne. Men dette forsvars karakter fremhæver netop, at Ordet og ikke nadveren er det primære. Som der står: "Jeg ser her Guds direkte, klare og magtfulde ord, som tvinger mig til den bekendelse, at Kristi legeme og blod skal være i sakramentet”. Det er altså Ordets magt, der sikrer kirkeritualets status. "Som der i Ordet ligger mere kraft end i Tegnet, således også mere $\mathrm{i}$ testamentet end i sakramentet". ${ }^{16}$

Ifølge Luther er Guds ånd altså først og fremmest nærværende i Ordet, dvs. i den kristne myte. Dette kan han ganske vist kun hævde, idet han samtidig fornægter denne mytes litterære heterogenitet. Den omfattende og sammensatte tekst, som udgør NT, præsenterer ifølge Luther udelukkende ét, nemlig Guds nådeshandling: "Den indeholder kun én enkelt forkyndelse og én enkelt mening" (BE, 83). En sådan ensidiggørelse af teksten må ikke forveksles med den centraliseringsbestræbelse, som middelalderallegorien er udtryk for. Formålet med allegorien var jo ikke blot at pege på visse mytologiske billeder eller litterære udsagn som rigtigere end andre, men at fremhæve mytologien som sådan som $u-$ egentlighed. I den henseende var netop mytologiens udstrækning og heterogenitet vigtig, fordi den kunne tjene til at fremhæve tekstens profane horisontalitet i modsætning til kirkeritualets symbolske vertikalitet. Den allegoriske praksis kan betragtes som vedligeholdelsen af et netværk af refererende betydning, der kun må opløses i én referent, i én meningsapoteose. I dette net fastholdtes mytologien, både den bibelske og den hedenske, i sin udstrækning og heterogenitet på en måde, der værnede imod opståelsen af decentrale vertikalbevægelser. Med Luthers lære derimod fornægtes bibeltekstens horisontale heterogenitet, til gengæld lanceres den i sin påståede ensidighed som menneskets primære adgang til den vertikale bevægelse.

På den baggrund er det muligt at forstå det som en tematisering af reformationens betydning for forvaltningsproblematikken, når Benjamin anfører lutherdommen som en forudsætning for den barokke allegoris melankolske blik. Ligesom mennesket med Luthers retfærdiggørelseslære ifølge Benjamin blev frataget den moralske orientering, blev allegorien $i$ og med opgøret med den middelalderlige tekstpraksis frataget sin veldefinerede opgave. Den menneskelige forvaltning af mytologien tilsidesattes til fordel for Ordets uformidlede magt. Altså: “De menneskelige handlinger var blevet frataget al værdi”. Ifølge Trauerspielbogen medvirker dette til udviklingen af den barokke melankoli: "Noget nyt opstod: en tom verden" (UT, IIg). Men hvis den melankolske fremstilling af verden som meningsforladt, som jeg har foreslået, ikke skal forstås som den barokke allegoris omstandighed, men derimod som dens bestrabelse, hvis det melankolske blik ikke beror på det meningsfravær, men på behovet for at bekæmpe det symbolske meningsnærvær, så må Benjamins hævdelse af, at lutherdommen fører til "eine leere Welt”, udlægges således: at lutherdommen intensiverer behovet for allegoriens melankolske tømning af det symbolske.

Et sådant intensiveret behov må følge af den lutherske tilbagegivelse af den kristne mytes symbolske aura. Med til reformationens omvæltninger hører nemlig den revolutionerende udbredelse af Ordet, som muliggjordes dels af Luthers bibeloversættelse, dels af opfindelsen af trykpressen. Med 
denne frisættelse af den kristne myte var den middelalderlige forvaltning af gudsnærværet definitivt afløst. Som Hörisch skriver:

Følgerne af denne demokratisering, der gjorde enhver il læser af Guds Ord, er uoverskuelige. De decentrerer bogstaveligt talt det semiotiske magtrum, der herefter ikke, uden særlig stadfæstelse, kender til noget "reelt" centrum"(BW, I22).

Erfaringen af Guds nærvær var nu ikke længere primært knyttet til kirkeritualet, men til Ordets klang i den enkelte kristnes indre. Netop denne lutherske decentralisering af gudsnærværet er blevet betragtet som en afgørende forudsætning for udviklingen af den moderne dyrkelse af kunsten som symbolsk nærværserfaring, dvs. den kunstdyrkelse, som Benjamin kritiserer i Goethe-tidens kunstfilosofi, og som han - konfronteret med de samtidige repræsentanter bl.a. i kredsen omkring Stefan George - søger at udfordre med sit allegoribegreb og aktualiseringen af den tyske barokdigtning. "I forkastelsen af

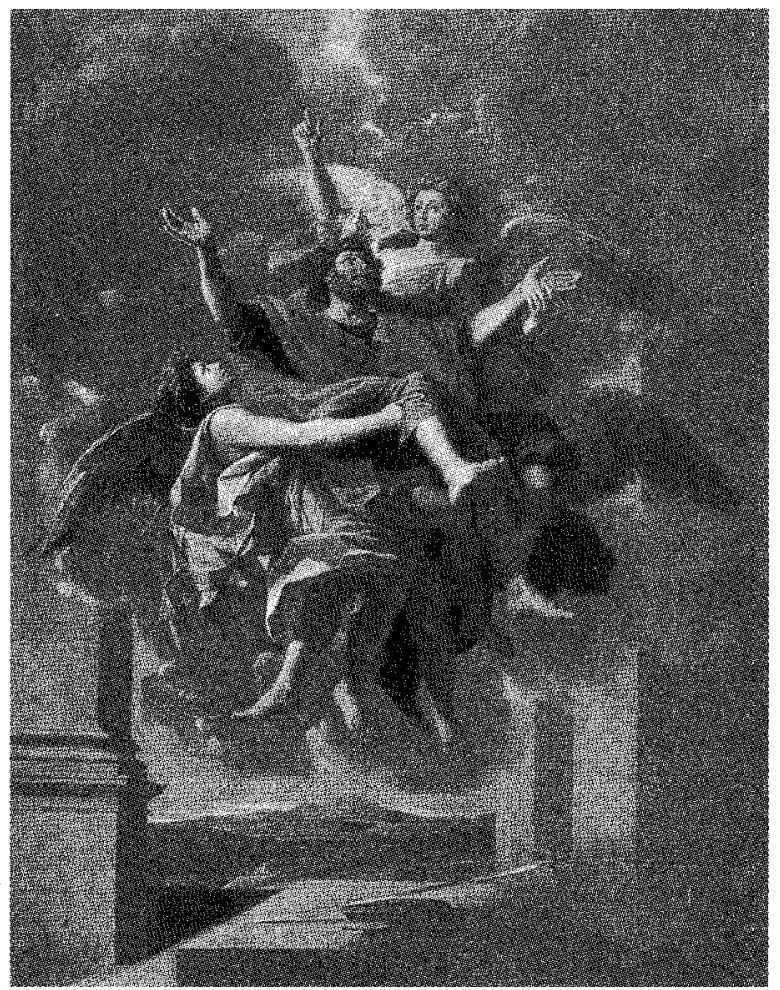

Paulus' omvendelse, Nicolas Poussin, I649-50 den åndelige allegoriske mening i skriftudlægningen, gjorde han den umiddelbare symbolske forståelse - i vor tids betydning af ordet - moderne" (AP, II, I3), hedder det hos Karl Borinski om Luther. Noget tilsvarende peger Manfred Schneider på, når han efter at have konstateret Ordets decentraliserende effekt - "at læseren via dette medium selv kan vinde direkte adgang til forjættelsen" - skriver, at "den moderne litteratur gennem en fuldstændig tilsvarende udvikling har opnået sin enestående mediale status [...] ikke som kommunikationsmedium, men som hellig tekst". ${ }^{17}$ Tilsyneladende skyldes Benjamins interesse for de lutherske barokdigtere altså ikke, at de skriver i en tom verden, men at de skriver i en verden fuld af frisat og potentielt dæmonisk mytologi: dels den som Ordet udbredte kristne mytologi og dels den i renæssancen genopblussede hedenske mytologi, der, ligeledes som følge af den lutherske forkastelse af allegorien, ikke kan afvæbnes på samme måde som hidtil.

For Luther synes troen på Ordets magt at have overdøvet frygten for gudebilledets dæmoni. Én mytisk magt overtrumfes af en anden. Dette skinner igennem i opgøret med den ikonoklastiske lære, som Karlstadt forenede med sin helligåndsteologi: Det er ifølge Luther ikke nødvendigt at bekymre sig om idolatri, thi "hvor hjerterne er blevet belært om at man kun behager Gud ved sin tro og ikke ved hjælp af billeder, om at disse hører til en forældet Gudsdyrkelse, opgiver menneskene af sig selv billederne" (WP, 139). Der behøves ingen allegori til at tæmme den ydre gudsbilledlighed, for $\mathrm{i}$ inderligheden forventes Ordet at foranledige de rigtige billeder. Som jeg har været inde på, kan Luthers reformation ses som en reaktion over for romerkirkens indladen sig på renæssancens nyhedenskab. Men bekymringen over for renæssancens indflydelse på kirken følges med en påfaldende ligegyldighed over for den gudsbilledlighed, som sættes fri i og med forkastelsen af middelalderallegorien. I opgøret med en mytologiinficeret kirke var der med andre ord ikke plads til den tanke, at mytologien, også den hedenske, netop måtte være i kirkeinstitutionens hænder, netop måtte indflettes $\mathrm{i}$ allegoriens uegentlighedsnet, for ikke at blive mytisk. 


\section{Allegoriens omslag}

At den barokke allegori ikke kan nøjes med at fremhæve mytologiens uegentlighed og henvise til kirkeritualet, men må fragmentere mytologien og fremstille "eine leere Welt", hænger sammen med opløsningen af den centraliserende kirkeinstitution. I bekæmpelsen af den frisatte mytologi må den, frem for at pege på det centrale gudsnærvær, fremhæve den totale gudsforladthed. Hermed kan den barokke allegori $\mathrm{i}$ sin fortvivlelse synes at nærme sig det ukristelige postulat, at også Kristus er fraværende, at mennesket ikke har modtaget nådegaven, men stadig befinder sig $i$ en verden, som den så ud umiddelbart efter syndefaldet. Den barokke allegori indebærer, som Benjamin skriver, en "opgivelse af eskatologien":

Hvor middelalderen stillede verdensbegivenhedernes ugyldighed og skabningens forgængelighed til skue som stationer på vejen imod frelsen, begraver det tyske sørgespil sig fuldstændig i den jordiske tilstands trøstesløshed(UT, 62).

Men dette er ikke det sidste. Ifølge Benjamin fører allegoriens fragmenterende og meningstømmende bestræbelser frem mod et omslag. Efter beskrivelsen af, hvorledes allegorien fremstiller sit materiale som arbitrært og meningsløst, hedder det således, "at alle disse betydningsrekvisitter netop i kraft af deres henvisning til noget andet vinder en magtfuldhed, der lader dem fremtræde som inkommensurable $\mathbf{i}$ forhold til det profane, der hæver dem op $i$ en højere sfære, ja sågar kan helliggøre dem" (UT, I53).

I forsøget på at forstå, hvad denne helliggørelse indebærer, kan det betale sig at skæve til Benjamins Über Sprache überhaupt und die Sprache des Menschen, hvorfra flere passager er gledet ordret ind i Trauerspielbogen. I denne jødisk prægede tekst arbejder Benjamin med forestillingen om det såkaldte navnesprog. Hermed menes det hellige sprog, som Gud efter skabelsen gav til Adam og Eva, for at de skulle kunne navngive det skabte. Med navnesproget følger en fordring: mennesket skal med sproget fuldende Guds skabelse: "Guds skabelse finder sin fuldendelse, idet mennesket giver tingene deres navne". ${ }^{8}$ I Paradisets Have var der således ikke tale om, at mennesket med sproget repræsenterede eller udtalte domme om fænomenerne. Det gav sprog til den skabte verden. Først ved syndefaldet opstod det repræsentative sprog, dvs. det sprog mennesket bruger til at sige noget om tingene. Med dette fald ud af "navnets evige renhed" (ÜS, I44) bliver menneskets sproglige aktivitet ifølge Benjamin voldelig. For det repræsentative sprog er ikke en videreførelse af Guds magt $\mathrm{i}$ benævnelsen af tingene, men et middel, hvormed mennesket forsøger at udøve sin egen magt over omverdenen.

Allegoriens omslag, helliggørelsen af 'betydningsrekvisitterne', skal efter alt at dømme forstås som den glimtvise genfindelse af navnesproget bag det faldne sprogs voldelighed. I denne bevægelse er allegorien imidlertid ikke blot oppe imod en menneskelig beherskelse af tingene. Efter syndefaldet sætter nemlig det, man kunne kalde idolatriens dialektik ind. Den meningstotalitet, hvormed mennesket forsøger at beherske tingene, vinder karakter af et sprogligt afgudsbillede, hvis mytiske udstråling overmander det beherskende menneske. ${ }^{19}$ Derfor italesætter Benjamin kampen for at frigøre det rene sprog fra det faldne sprogs meningsovergreb som en kamp imod idolatrien, og derfor spejles hans beskrivelse af, hvorledes allegorien arbejder imod sproget for dermed at kunne redde det, $\mathrm{i}$ beskrivelsen af barokdigternes kamp imod de antikke gudebilleder. Skulle nogen have fundet forståelsen af det mytiske som potentielt dæmonisk gudsbilledlighed en tand for kulørt, så har de her den direkte kobling til den kritiske teoris mere abstrakte mytekritik. Fordi det faldne sprog ligger under for idolatriens dialektik, er kampen imod menneskenes sproglige vold hos Benjamin uadskillelig fra kampen imod gudebilledernes dæmoni. "Prudentius' spådom: "Renset for al blod vil marmoret endelig stråle; uskyldige vil de bronzefigurer stå, der i dag betragtes som idoler", denne spådom", hed det, "er endnu ikke tolvhundrede år senere gået i opfyldelse” (UT, 200). Den mytiske vold er med andre ord stadig virksom.

Det faldne sprogs voldelighed udfolder sig altså i to dialektisk forbundne bevægelser: I. den menneskelige beherskelse af sproget og tingene, og 2 . denne beherskelses omslag $\mathrm{i}$ afmagt, når de menne- 
skelige meningspostulater afslører deres karakter af gudebilleder, og den påkaldte dæmoni sætter sig igennem. Den barokke allegoris potentiale er i forste omgang en modarbejdelse af denne anden bevægelse, idet den bryder den poetiske Mythos' tryllekreds, og den menneskelige magt over betydningsdannelsen genoprettes: "Idet genstanden under det melankolske blik bliver allegorisk, tømmes den for liv, og den ligger død tilbage, men i evigheden sikret. Således ligger den foran allegorikeren, udleveret til hans nåde og unåde" (UT, I6r). På denne måde frigjort fra den mytiske besættelse har allegorikeren muligheden for igen at underkaste sig guds fordring, at genoptage sprogopgaven, ${ }^{20}$ idet han lader betydningsfragmenterne indgå som brikker $i$ et sprogligt konstellationsarbejde.

Hvis det allegoriske arbejde på den måde kan bestemmes som bekæmpelsen af symbolets magt med henblik på en utopisk genfindelse af navnesproget, kan det forvirre, at Benjamin i fortalen til Trauerspielbogen (UT, I8) vælger at forbinde forestillingen om "navnet" med netop symbolbegrebet. Dette kan give anledning til den opfattelse, at den symbolske 'Sinnerfüllung' både er genstanden og den messianske horisont for allegoriens negative arbejde. Christoph Lienkamp f.eks. drager en sådan konklusion. Når Benjamin kritiserer det klassicistiske symbolbegreb under henvisning til det teologiske, forstår Lienkamp det derfor som en installation af sidstnævnte som horisont for allegoriens dialektik: "Hans kritik gælder ikke symbolet $i$ det hele taget, men kun "den tilsnegne anvendelse af denne tale om det symbolske", i hvilken spændingen imellem modsætningerne opløses" (MU, 48). På den måde bliver allegoriens dialektik cirkulær: den begynder og ender $i$ det symbolske. Som allegorien er et korrektiv til det præsente symbols dæmoni, således er det symbolske som horisont ifølge Lienkamp et korrektiv til allegoriens vilkårlighed, idet denne underkastes "en teologisk kritik, der fastholder symbolet, enheden af den sanselige og den oversanselige genstand, som pant på den messianske forløsning” (MU, 5I). Som jeg til slut skal vende tilbage til, er det oplagt og vigtigt, at Benjamin, som Lienkamp peger på, er interesseret $\mathrm{i}$ muligheden for at vende den symbolske udstråling imod den allegoriske beherskelse. Derfor er den cirkulære model besnærende. Ikke desto mindre synes det mest frugtbart at fastholde en mere lineær forståelse af allegoriens dialektik. Det symbolske, som allegorien sætter ind over for, er nemlig efter alt at dømme ikke sammenfaldende med det navnesprog, der udgør dens horisont. Førstnævnte fremwæder som mytisk gudsnærvær, det - med Lévinas' terminologi - sakrale. Navnesproget derimod som Guds fordring, det hellige. ${ }^{2 x}$

\section{Faldet fra Torah'en}

Jeg indledte med Lévinas' bestemmelse af den jødiske skriftreligion. Med udgangspunkt $i$ forestillingen om navnesproget som hellig sproglighed, har Susan A. Handelman forsøgt at forbinde Benjamin med Torah-tænkningen, som hun finder den hos Lévinas og Franz Rosenzweig. Ligesom Torah'en er Benjamins navnesprog, og således selve hans forestilling om en uvoldelig relation menneske og verden imellem, forbundet med det jødiske dogme om trofasthed over for Guds fordring. Men som Handelman selv peger på, er det afgørende, på hvilken side af syndefaldet den gudssanktionerede sproglighed menes at have sin gyldighed:

Lévinas vil tilslutte sig Rosenzweigs opfattelse af dette sprogets åbenbaringspotentiale som værende til rådighed nu og her, og ikke som tabt i en mytisk fortid, hvorfra vi er faldet. Sprogets etiske væsen vil således både for Lévinas og Rosenzweig bekræftes via det konkrete indhold af den jødiske lov. ${ }^{22}$

Derimod fremtræder Benjamin som en jøde uden Torah. ${ }^{23}$ Hvor Torah'en hos Lévinas så at sige borger for det kommunikative sprog og udtrykker den uendelige etiske fordring (at menneskene skal tale med hinanden), indebærer Benjamins sprogopfattelse en fundamental mistillid til de kommunikative sprog. For ham handler det derfor ikke om at holde sig til det hellige sprog som en given positivitet, men om at modarbejde det mytiske sprog, for at holde en messiansk mulighed åben.

Man finder hos Benjamin en slags forskydning af den frelseshistoriske grundmodel, hvorudfra den elementære forskel på kristendom og jødedom hos 
både Lévinas og Handelman, bestemmes. En sådan model vil bestemme I. syndefaldet som et tab af et oprindeligt gudsnærvær; 2. den jødiske Torah som relationen til Gud efter faldet - en relation, der indebærer fordringen og sprogets hellighed og varer indtil Messias' komme; 3. Kristus som den kontroversielle hævdelse af denne Messias' komme, Guds nådige eftergivelse af fordringen og genoprettelse af det tabte nærvær. Ifølge denne model hænger faldenhed og Torah altså sammen. I forbindelse med Benjamin er det herimod mere rammende at tale om syndefaldet som et fald ikke fra gudsnærværet, men fra Torah'en, dvs. et fald, hvorved sprogets hellighed forpestes, og arbejdet med fordringen derfor bliver problematisk. Syndefaldet gør det nødvendigt at arbejde negativt med sproget, men ikke for at finde et gudsnærvær hinsides sproget, som det kunne være en kristen mystiks ambition, derimod for at genfinde den oprindelige sprogopgave. Benjamin gør i sprog-essayet eksplicit op med enhver tavshedsmystik, der søger "det endegyldige åndelige væsen" i "uudtalelighedens perspektiv" (ÜS, I46). Formålet med det negative sprogarbejde, f.eks. allegoriens fragmentering af det litterære materiale, er, som det hedder i Trauerspiel-bogen, "blikket i sprogets dyb" (UT, I78).

Ved at holde sig denne negativt jødiske position for øje er det måske muligt at forklare Benjamins interesse for de tyske barokdigteres desperation. I bekæmpelsen af den litterære nyhedenskab savnede den barokke allegori et symbolsk centrum at orientere sig imod. Allegorien, hvis centraliseringsbestræbelse truedes yderligere af den lutherske læres frigivelse af den kristne myte, måtte i denne situation fornægte selve Kristi nærvær og lade verden fremtræde som gudsforladt. Det er ved denne "opgivelse af eskatologien”, at Benjamins negative jødedom kan knytte an til barokkens fortvivlede kristendom. For hvis man tager Kristus fra en kristen og Loven fra en jøde, så står de stort set det samme sted, i den rene faldenhed, og det er denne situation, som Benjamin interesserer sig for som udgangspunkt for en genopdagelse af det tabte navnesprog.

Placeret på dette sted i frelseshistorien, endnu ikke forstyrret af hverken Lovens legitimering af det kommunikative sprog (jf. Lévinas) eller af den kristne nærværserfaring, er det muligt - og dette synes at være Benjamins ambition på kunstens og kunstkritikkens vegne - at høre tingene, der sørger over ikke at blive benævnt: "Også den hele natur gennemstrømmes nemlig af et navnløst stumt sprog, en rest af det skabende gudsord, som stadig findes i mennesket som erkendende navn og svævende over mennesket som domsfældelse" (ÜS, I57). Idet opmærksomheden rettes imod tingenes tavse klagesang, dvs. imod ofrene for den mytiske voldelighed, som historien efter syndefaldet har medført, erindrer mennesket Guds fordring, der stadig, trods faldet fra sproget, står ved magt. På den måde finder den barokke allegoriker sig selv "ikke længere legende $\mathrm{i}$ den jordiske tingsverden, men derimod alvorsfuldt under himlen" (UT, 208). Den orientering imod transcendensen, som allegorien foranlediger, hænger således uløseligt sammen med omsorgen for immanensen. Fordringen, som allegorikeren vågner op til, gælder den uvoldelige omgang med det skabte.

Forudsætningen for helliggørelsen af sproget er som sagt modarbejdelsen af det andet led i idolatriens dialektik, dvs. besættelsen. I reaktualiseringen af den rene faldenhed neutraliserer den barokke allegori den poetiske Mythos' symbolske magt og tilbagevinder dermed den menneskelige magt over betydningerne. Med dette udgangspunkt kan konstellationsarbejdet begynde. Genindsat i den beherskendes position kan allegorikeren imidlertid forføres af sin subjektive almagt og glemme fordringens objektivitet. Denne magtbesættelse, drevet af "illusionen om den absolutte, dvs. gudsløse, åndeligheds rige”, betegner Benjamin - med sigte bl.a. til en romantisk dyrkelse af subjektivitetens uendelighed - som djævelskab. Med begrebet om den djævelske allegori, denne "frigørelse fra det hellige" (UT, 206) som det ikke her er muligt at komme nærmere ind på - tematiseres en situation, der kan nødvendiggøre en genopvækkelse af den poetiske Mythos' symbolske udstråling i kampen imod subjektivitetens almagt - med andre ord, en mobilisering af dæmonien imod djævelskaben. I beskrivelsen af en sådan manøvre er det relevant som Lienkamp at hævde sym- 
bolets nødvendighed "som grundlag for en kritik af den overdrevne allegoriske subjektivitet og dennes almagt over for tingene" (MU, 53). Men det symbolske fungerer i denne forbindelse som et middel i bekæmpelsen af den djævelske allegoris subjektivitet og ikke, som Lienkamps cirkulære dialektik-forståelse indebærer, som den messianske horisont for allegoriens helliggørende arbejde. Måske i kraft af denne strategiske genopvækkelse af det mytiske som middel fremtræder Benjamins kritiske arbejde med litteraturen i praksis væsentligt mindre ikonoklastisk, end udlægningen her kan have givet indtryk af.

\section{Noter}

I. Difficile Liberté, Paris, 1963, s. 204.

2. Netop disse kvaliteter lægger Susan A. Handelman vægt på i sin lancering af det, man kunne kalde en 'jødisk tekstualisme'. I bøgerne The Slayers of Moses og Fragments of Redemption opstiller hun ved læsninger af Freud, Lacan, Derrida, Bloom, Scholem, Benjamin og Levinas en forestilling om bogstavets uendelighed over for ambitionen om at ophæve tekstens betydning $i$ en meningsapoteose. 3. "Späthorizonte des Mythos in biblischer und christlicher Überlieferung" i Poetik und Hermeneutik IV: Terror und Spiel, München, I97I, s. 519. Herefter SM.

4. Dialektik der Aufklärung, Frankfiurt a.M., I969, s. I86.

5. Messianische Ursprungsdialektik - die Bedeutung Walter Benjamins für Theologie und Religionsphilosophie, Frankfurt a.M., I998, s. 32. Herefter MU.

6. Heri støtter jeg mig til Jochen Hörisch, der i Brot und Wein bestemmer nadverritualet som middelalderkirkens absolutte kultiske centrum. Se Brot und Wein, Frankfurt a.M., I992, s. I6. Herefter BW.

7. Se Jens Glebe-Møller: Med venner i lys vi tale, Kbh., I993, s.83.

8. "Allegorese, Remythisierung und Neuer Mythos" i Poetik und Hermeneutik IV: Terror und Spiel, München, I97I, s. I9I. Herefter AR.

9. Die Antike in Poetik und Kunsttheorie, Leipzig, I9I4, Bd. I, s. I9I. Herefter AP.

ro. Dette i direkte modsætning til den forståelse af allegorien, bl.a. at finde hos Harald Steinhagen, der tager udgangspunkt i verdens totale meningsløshed og derefter ser allegorien som et forsøg på at opbygge illusionen af mening. Se "Zu Walter Benjamins Begriff der Allegorie" $i$
Formen und Funktionen der Allegorie, Stuttgart, 1978.

Ir. Heidnisch-Antike Weissagung in Wort und Bild zu Luthers Zeiten, Gesammelte Schriften I.2, Berlin I998, s. 49I. UT s. 202.

I2. "Die prophetische apokalyptik Thomas Müntzers und Luthers Absage an die Bauernrevolution" $i$ Thomas Müntzer, Darmstadt, 1978, s. 6.

13. Wider die himmlichen Propheten, von Bildern und Sakrament, Luther Deutsch bd. IV, Göttingen, I99I, s. I48. Herefter WP.

I4. Auff das uberchristlich, ubergeistlich und uberkunstlich buch Bock Emsers zu Leipzig, Halle, I892, s. 83. Herefter BE.

I5. "Det er ikke nok at forstå, man må også opleve teksten [...] Ordet er den objektiverede guddommelige realitet”. Således opsummerer Darrel R. Reinke Luthers opfattelse. 'From Allegory to Metaphor' i Harvard Theological Review vol. 66. Se endvidere Hans Wernle: Allegorie und Erlebnis bei Luther, Bern, 1960.

I6. Von der babylonischen Gefangenschaft der Kirche, Luther Deutsch bd. II, Göttingen, I99I, s. I92.

I7. "Luther mit McLuhan" i Diskursanalysen I, Opladen, 1987, s. 20 og 22. En lignende pointe finder man hos Hörisch (B W, I42) og hos Hans Georg Gadamer (Wahrheit und Methode, Tübingen, I965, s. I21).

I8. Über Sprache überhaupt und die Sprache des Menschen, GS bd.II.I, Frankfurt a.M., s. I44. Herefter ÜS.

I9. Måske derfor gælder billedforbuddet ikke blot repræsentationen af det guddommelige, men enhver repræsentation.

20.Jf. Benjamins gennemgående italesættelse af det litterære og det kritiske arbejde som svar på en fordring, som f.eks i titlen Die Aufgabe des Übersetzers og i Zwei Gedichte von Friedrich Hölderlin, hvor ordet "Aufgabe" blot på den første side optræder ikke mindre end otte gange. GW II. I, s. I05.

2I. Det virker derfor forbløffende, når Jens Glebe-Møller finder på at identificere navnesproget med Helligånden. Med venner $i$ lys vi tale, s. $68 \mathrm{ff}$.

22. Fragments of Redemption, Indianapolis, I991, s. 70.

23. Handelman forsøger sig her med en kulturhistorisk forklaring: Fremmedgørelsen over for Torah-traditionen, som er karakteristisk for mange af periodens centraleuropæiske jøder, hænger sammen med, at de foregående generationer i forhippelsen på at assimilere sig havde forsømt deres jødiske kultur. 'Det var dette 'selvbedrag', der virkede så frastødende på Scholem, Kafka, Benjamin, Freud og andre forfattere, som kom fra disse familier."(Fragments of Redemption, s. 7I). 